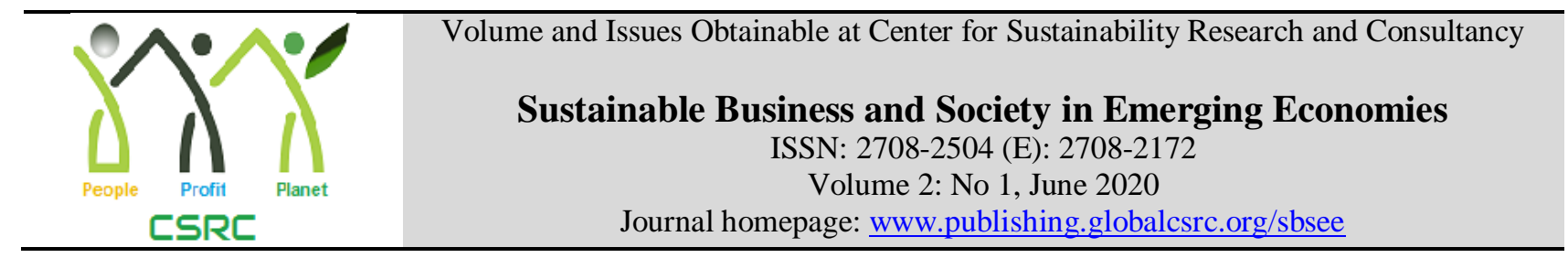

\title{
A Conceptual Paper on Corporate Social Responsibility among Malaysian Entrepreneurs
}

\section{${ }^{1}$ Tengku Anis Syafiqah Tengku Jasmi, ${ }^{2}$ Nazlina Zakaria, ${ }^{3}$ Lily Julienti Abu Bakar}

${ }^{1}$ Faculty of Economics and Management, Universiti Putra Malaysia, Malaysia. anisjasmi@gmail.com

${ }^{2}$ School of Business Management, Universiti Utara Malaysia, Malaysia. nazlina@uum.edu.my

${ }^{3}$ School of Business Management, Universiti Utara Malaysia, Malaysia, julienti@uum.edu.my

\begin{tabular}{|c|c|}
\hline ARTICLE DETAILS & ABSTRACT \\
\hline $\begin{array}{l}\text { History } \\
\text { Revised format: May } 2020 \\
\text { Available Online: June } 2020\end{array}$ & $\begin{array}{l}\text { Conflicting views on corporate social responsibility have led to } \\
\text { various studies on CSR. However, the previous studies focused } \\
\text { mainly on large firms rather than small and medium entrepreneurs. }\end{array}$ \\
\hline $\begin{array}{l}\text { Keywords } \\
\text { Corporate social } \\
\text { responsibility, entrepreneur, } \\
\text { SMEs }\end{array}$ & $\begin{array}{l}\text { of small and medium enterprises. This is because any initiatives } \\
\text { taken by small and medium enterprises can affect society and the } \\
\text { economy due their large contributions. Therefore, this paper }\end{array}$ \\
\hline JEL Class & urs, mainly small and medium enterprises. \\
\hline
\end{tabular}

(C) 2020 The authors, under a Creative Commons Attribution-

OPEN ACCESS NonCommercial 4.0

Corresponding author's email address: anisjasmi@gmail.com

Recommended citation: Jasmi, T. A. S. T., Zakariya, N., Bakar, L. J. A. (2020). A Conceptual Paper on Corporate Social Responsibility among Malaysian Entrepreneurs. Sustainable Business and Society in Emerging Economies, 2(1), 13-19

\section{Introduction}

When corporate social responsibility (CSR) was first introduced, it received backlashes and was not widely accepted by businesses. There were negative views and critiques regarding CSR. Not only that, multiple views from different scholars also emerged (Carroll, 1979; Jamali, Zanhour, \& Keshishian, 2009). This occurred because the notion of CSR is the opposite of what businesses are perceived to be. Businesses focus primarily on profit-maximizing, which is a conventional way of conducting business. It should prioritize making profits by fully utilizing its resources and in the mean-time still abide by the law, instead of focusing on social responsibility which would incur additional costs to the business (Friedman, 1970). However, year to year and due to the emergence of the economy as well as societal expectations from the society and the stakeholders, many businesses have implemented CSR because they are aware of the importance and the good effect of CSR (Pedersen, 2015). Compared to before, there has been a shift in the prime focus of social responsibilities (Carroll, 1979). This CSR evolution can be seen in the social responsibility aspects in businesses, as for example, workers' rights, occupational health and safety, and work equity. In the past, social responsibility aspects, such as occupational health and work equity were 
not the concerns of a firm. Businesses in the present day have become more responsible in conducting their businesses by making the acts regarding social responsibility as obligatory regulations.

In Malaysia, there are numerous strategies and approaches carried out by the government and related bodies to increase the implementation of CSR, not only in large firms but also in small and medium enterprises (SMEs) (UNICEF, 2013). Most of the studies have focused on large firms as it is mandatory for large firms to conduct and report their CSR activities; meanwhile, SMEs are not obliged to report their CSR activities, if any (UNICEF, 2013). Therefore, until now, studies on CSR in the context of SMEs have not been widely explored.

\section{The Concept of Corporate Social Responsibility}

One of the main reasons for the issues related to CSR is its broad concept. There is no standard definition or definite definition in describing CSR (Marrewijk, 2003). Various definitions and concepts have emerged from the debates that have been articulated year by year.

It all started when Howard R. Bowen, who is renowned as the Father of CSR published the first work on the concept of CSR in 1953 through his book Social Responsibilities of the Businessman. As seen from the title, previously CSR was only known as the social responsibility of a business. This is because, the role of the businessmen was not widely acknowledged during that era. Bowen's publication has sparked numerous debates on CSR.

On the contrary, a different view from Milton Friedman emerged in 1970. This was an important stage in developing the idea of CSR. This is because, the view from Friedman was contrastive from other views around that era. Friedman (1970) did not reject the idea of CSR. Instead, Friedman argued that the primary social responsibility of a business is to increase profits by using its resources effectively and getting involved in profitable activities while obeying the laws, such as to not be involved in fraud, illegal methods or dishonesty. Additionally, his work also clearly stated the scope of CSR, its connection to shareholders and owners, as well as its link to profit maximization (Friedman, 1970).

Furthermore, the Companies Commission of Malaysia (2013) defined CSR as the willingness of corporations and businesses to work on sustainability in terms of social, economic and environmental aspects while also focusing on making profits. In addition, UNICEF (2013) defined CSR as the upmost action in abiding by the law by a group of voluntary businesses. Moreover, the World Business Council for Sustainable Development (n.d.) defined CSR as the willingness and the ongoing commitment of a business to develop the economy and at the same time enhance the employees and their families, the community and the society's quality of life as a whole.

Despite the numerous definitions, CSR can be clearly explained by using a Three-Dimensional Conceptual Model of Corporate Performance. This model was developed by Archie B. Carroll in 1979 and it consists of four dimensions, namely economic responsibilities, legal responsibilities, ethical responsibilities, and discretionary responsibilities. These responsibilities must be satisfied for a firm to become socially responsible.

The first dimension is economic responsibilities. Economic responsibilities are the basic responsibilities that need to be carried out. Generally, a business is the basis in an economic system in a society. Providing goods and services necessary for the members of the society and simultaneously making profits from them are the widely established economic responsibilities accepted by firms (Carroll, 1979). The second dimension is legal responsibilities. Just as with the economic responsibilities, the implementation of legal responsibilities by firms is highly anticipated by the society. This is because, the society expects firms to comply with the judiciary, rules and guidelines while conducting their businesses (Carroll, 1979; Crane, Matten, \& Spence, 2013). The third dimension is ethical responsibilities. There are no standardized instructions in conducting ethical responsibilities for firms to follow, nor are they stated in the law. 
Nevertheless, the society looks forward to firms' implementation of them. This shows that the expectation of society is beyond the legal responsibilities. Furthermore, the vague definition of ethical responsibilities makes it the hardest of all the responsibilities for firms to comply with (Carroll, 1979). The last dimension is discretionary responsibilities. This is the most favorable of the responsibilities to be carried out by firms among the others. It is common for Malaysian firms to conduct discretionary responsibilities. Compared to ethical and legal responsibilities, society anticipates the social roles of firms the most, but it depends on one's judgement, values and beliefs. In addition, this responsibility is considered as voluntary work and is inclined towards a firm's willingness to engage in social roles rather than seeing it as an obligation. The examples of discretionary responsibilities are donations, disaster relief, free medical check-ups and organizing talks on health awareness (Carroll, 1979).

Therefore, CSR can be defined as the incorporation of economic, legal, ethical and discretionary expectations of society towards firms at a certain period as the social responsibility of business (Carroll, 1979).

Not only does it have various definitions, CSR also has multiple terminologies (Carroll, 1979; Companies Commission of Malaysia, 2013; Nejati \& Amran, 2013; UNICEF, 2013). Corporate Responsibility; Sustainability; Sustainable Development or Business Practice; Corporate Citizenship; Responsible Business Practice; Environmental Involvement; Environment, Social and Governance and Triple Bottom Line are the alternative terminologies for CSR (Companies Commission of Malaysia, 2013; Nejati \& Amran, 2013; UNICEF, 2013). Different terminologies are used according to the variety of the perceptions, conceptualizations and definitions in CSR (Carroll, 1979).

\section{Corporate Social Responsibility in Malaysia}

The Malaysian government has made it an obligation for public-listed companies (PLCs) to disclose and report their CSR activities (Companies Commission of Malaysia, 2013; UNICEF, 2013). According to UNICEF (2013), there are no reporting requirements for government-linked companies (GLCs) and SMEs. It can benefit firms in transparency, encourage innovation, enhance reputation, minimize corporate risk, and attract favorable financing conditions (Companies Commission of Malaysia, 2013). The disclosure must be categorized into four categories, namely marketplace content, workplace content, community content, and environment content (Companies Commission of Malaysia, 2013; UNICEF, 2013). These categories hold different characteristics that needs to be reported accordingly to the stakeholders (Companies Commission of Malaysia, 2013).

Firstly, marketplace content. This content illustrates the implementation of socially responsible practices in conducting the business, such as providing help and support to the local businesses and suppliers, customer retention, customer satisfaction, safety and quality of products and services, marketing, advertising, and ethical work conduct (Companies Commission of Malaysia, 2013). However, not all firms implement CSR initiatives in their supply chain (UNICEF, 2013). Additionally, there might be an adequate understanding on the responsibility of products or services (UNICEF, 2013). According to the Companies Commission of Malaysia (2013), the focus stakeholders for marketplace content are customers, business partners and investors.

Secondly is workplace content. In this content, a firm reports the benefits and support provided. For instance, salaries, pensions, employees' benefits, health and safety requirements, nursing facilities, adequate staff training, equality in employment, diversity, bribery and fraud policies, and employees' work life balance (Companies Commission of Malaysia, 2013). This can be a drawback to firms with no related policies, such as flexible office hours, diversity coaching or training and childcare amenities (UNICEF, 2013). According to the Companies Commission of Malaysia (2013), the focus stakeholders for workplace content are employees, public authorities and trade unions. 
Thirdly, community content. This content provides details on volunteering activities as well as charitable donations and sponsorship that contribute to economic development. The details can consist of improving the quality of amenities and systems in the community, engaging with the locals and healthcare and education of the community (Companies Commission of Malaysia, 2013). This content may contain philanthropic activities rather than other related activities (UNICEF, 2013). According to the Companies Commission of Malaysia (2013), the focus stakeholders for community content are employees, public authorities and related local authorities.

Lastly, environment content. This content demonstrates the actions taken to protect and preserve the environment. Reducing the hazardous gas emissions, waste and environmental pollution, such as water and air, using renewable energy, checking and supervising the firm's energy usage and keeping biodiversity in existence are the examples of this content (Companies Commission of Malaysia, 2013). UNICEF (2013) reported that almost $25 \%$ of the firms provide no data. According to the Companies Commission of Malaysia (2013), the focus stakeholders for environment content are employees, business partners, investors, consumers, public authorities and the local community.

CSR disclosure and reporting, awards, as well as guidelines provided by the Malaysian government and related organizations are the government's initiatives to introduce CSR to businesses. Other than CSR disclosure and reporting, there are awards specifically given to firms with remarkable impacts of their CSR programs and activities in order to increase the awareness and the implementation of CSR in the Malaysian firms. There are the Prime Minister's CSR awards which comprise a variety of categories, namely the Community and Social Welfare, Cultural and Heritage, Education, Environment, Small Company CSR, Best CSR/Workplace Practices, Empowerment of Women, Special Award-Media Reporting, Best Overall CSR Program, Family Friendly Workplaces and Outstanding Opportunities for People with Disabilities (UNICEF, 2013). The award that was introduced in 2007 has been won by numerous renowned large firms, such as DiGi, CIMB, Telekom Malaysia, MEASAT Broadcast Network Systems, and IBM Malaysia Sdn. Bhd. (UNICEF, 2013). Additionally, the ACCA Malaysia Sustainability Reporting Awards (ACCA MaSRA) has recognized firms in terms of their sustainability report as part of the firms' annual reports (Companies Commission of Malaysia, 2013).

\section{Corporate Social Responsibility in Malaysian Small and Medium Enterprises}

The term "corporate" that is used in corporate social responsibility imposes confusion for SMEs. This is because, the term "corporate" is usually associated with large firms (Crane et al., 2013). Therefore, can corporate social responsibility be implemented in SMEs when there are differences in both large firms and SMEs?

SMEs are known for their important roles in the economy as well as their limitations and challenges. Limited resources, financial constraints, low number of employees and lack of knowledge and skills are examples of the challenges faced by SMEs (Musa \& Chinniah, 2016). These challenges are some of the distinct features of SMEs and large firms.

However, in terms of CSR, challenges and limitations can act as advantages depending on the circumstances. One of the examples is that the low number of employees in SMEs can make it easier for changes to be implemented. One of the reasons is that, it is easier for the staff to receive the training and knowledge required with a reasonable cost because of the small number of employees. Thus, this will ease the process of implementing CSR in SMEs.

In Malaysia, the awareness of SMEs on CSR was reported to be at the medium level and has been perceived as a positive view (Abdullah, Mohamad, \& Mahat, 2015; Mohd Nasir, Abdul Halim, Mohd Sallem, Jasni, \& Aziz, 2015). Malaysian SMEs are commonly involved in CSR through monetary donations, property donations and providing assistance to communities in need (Abdullah et al., 2015). 
As stated earlier, the government has required that the firms disclose and report their CSR activities. However, there is a difference in the reporting and disclosing of CSR between listed companies and SMEs. Unlike large firms, SMEs are not obliged to report their CSR activities due to the lack of resources and financial constraints that SMEs face (Companies Commission of Malaysia, 2013). However, in spite of the constraints, SMEs can still get involved with CSR activities. One of the ways for SMEs to conduct CSR activities is by collaborating with large firms in conducting the activities. Yet, it can be more beneficial for large firms as they will get the most exposure, such as from the media (Preuss, 2011).

Other than that, SMEs can consociate with large firms to carry out CSR activities through the supply chain (Companies Commission of Malaysia, 2013; Inyang, 2013). Large firms may implement CSR standards in the supply chain which need to be adhered to. If SMEs were to implement the standards on their own, they would have to bear the high costs that are incurred in the process, such as essential resources and skills (Ciliberti, Pontrandolfo, \& Scozzi, 2008). Therefore, it is better for SMEs to work together with large firms. This shows that despite the limitations encountered by the SMEs, there are ways that SMEs can be associated with CSR.

In the context of CSR studies in Malaysia, previous studies focused more on the relationship between CSR and the non-financial performance of firms as well as CSR disclosures (Mohd Nasir et al., 2015). Moreover, the studies also focused on large firms. As mentioned earlier, findings on large firms cannot represent SMEs due to the differences in their characteristics, limitations and challenges.

It is vital to conduct a study and explore CSR in the context of SMEs. This is because of the large contribution on SMEs to Malaysia's economy. The contributions are primarily in terms of GDP and total employment (SME Corporation Malaysia, 2018). Table 1 portrays the distribution of the SME GDP from various economic sectors of SMEs (SME Corporation Malaysia, 2018).

\section{Table 1: SME GDP by Key Economic Sector (constant 2010 prices)}

\begin{tabular}{|l|c|c|c|c|}
\hline \multirow{2}{*}{$\begin{array}{c}\text { SME GDP by } \\
\text { Economic } \\
\text { Sector }\end{array}$} & \multicolumn{3}{|c|}{ SME Contribution to GDP } & SME GDP Growth \\
\hline Overall & 2010 & 2017 & $\begin{array}{c}\text { Increase / } \\
\text { decrease in } \\
\text { share }\end{array}$ & $\begin{array}{c}\text { CAGR }^{1} \\
\text { 2011-2017 (\%) }\end{array}$ \\
\hline Agriculture & $\mathbf{3 2 . 2}$ & $\mathbf{3 7 . 1}$ & $\mathbf{+ 4 . 9}$ & $\mathbf{6 . 6}$ \\
\hline Mining \& Quarrying & 4.3 & 4.1 & -0.2 & 2.9 \\
\hline Manufacturing & 0.05 & 0.2 & +0.15 & 9.1 \\
\hline Construction & 7.2 & 8.0 & +0.8 & 6.4 \\
\hline Services & 0.9 & 2.2 & +1.3 & 9.7 \\
\hline
\end{tabular}

Thus, with their significant roles in Malaysia's economy, any social and environmental initiatives taken by SMEs are crucial and become an important contribution to the society as well as give positive impacts to the society and the economy (Companies Commission of Malaysia, 2013).

Additionally, the implementation of CSR can help to benefit businesses in numerous ways. Firstly, it can increase competitive advantage (Companies Commission of Malaysia, 2013). By having CSR, it can differentiate products and services from other brands. Furthermore, as the customers are more aware of the issues regarding the environment and the workplace, such as climate change and inequality in the 
workplace, they are more inclined to choose products that are manufactured under responsible conditions (Companies Commission of Malaysia, 2013). This can help SMEs to improve their businesses and get recognized by potential customers. Secondly, CSR can also help in retaining employees (Azman \& Mustapha, 2018; Thorne, Ferrell, \& Ferrell, 2011). Policies related to responsible work conduct, such as work life balance, safety and health requirements and equality in the workplace can strengthen employees' loyalty (Companies Commission of Malaysia, 2013).

\section{Conclusion}

There is a positive and increasing advancement in the study of CSR in Malaysia. Previous studies have focused on large firms instead of SMEs as well as the disclosure and reporting of CSR. Therefore, it is important to close the gap in the CSR literature by exploring CSR in the context of SMEs. Furthermore, future studies can contribute to the body of knowledge by considering other factors that contribute to the implementation of CSR in the future.

\section{References}

Abdullah, S., Mohamad, A., \& Mahat, N. I. (2015). Kesedaran Terhadap Tanggungjawab Sosial Korporat (CSR) dalam Kalangan Usahawan Kecil dan Sederhana di Malaysia. Journal of Global Business and Social Entrepreneurship, 1(1), 77-84.

Azman, N. A. H., \& Mustapha, M. (2018). Benefits and challenges of corporate social responsibility implementations: Evidence from manufacturing sector in Malaysia. International Journal of Engineering and Technology(UAE). https://doi.org/10.14419/ijet.v7i2.29.13320

Carroll, A. B. (1979). A Three-Dimensional Conceptual Model of Corporate Performance. Academy of Management Review, 4(4), 497-505. https://doi.org/10.5465/AMR.1979.4498296

Ciliberti, F., Pontrandolfo, P., \& Scozzi, B. (2008). Investigating corporate social responsibility in supply chains: a SME perspective. Journal of Cleaner Production, 16(15), 1579-1588. https://doi.org/10.1016/j.jclepro.2008.04.016

Companies Commission of Malaysia. (2013). Best Business Practice Circular 5/2013 Corporate Responsibility: Guidance to Disclosure and Reporting, 1-24. Retrieved from http://www.ssm.com.my/en/CRAgenda/

Crane, A., Matten, D., \& Spence, L. J. (2013). Corporate Social Responsibility: Readings and Cases in a Global Context. In Corporate social responsibility: Readings and cases in a global context (pp. 326). Routledge. https://doi.org/10.1080/00207233.2013.841036

Friedman, M. (1970). The Social Responsibility of Business is to Increase its Profits. New York Times Magazine, 6(Newspaper Article), 33,122-126. Retrieved from http://www.nytimes.com/

Inyang, B. J. (2013). Defining the Role Engagement of Small and Medium-Sized Enterprises (SMEs) in Corporate Social Responsibility (CSR). International Business Research. https://doi.org/10.5539/ibr.v6n5p123

Jamali, D., Zanhour, M., \& Keshishian, T. (2009). Peculiar strengths and relational attributes of SMEs in the context of CSR. Journal of Business Ethics, 87(3), 355-377. https://doi.org/10.1007/s10551-0089925-7

Marrewijk, M. van. (2003). Concepts and definitions of CSR and corporate sustainability: Between agency and communion. Journal of Business Ethics, 44(2), 95-105. https://doi.org/10.2307/25075020

Mohd Nasir, N. E., Abdul Halim, N. A., Mohd Sallem, N. R., Jasni, N. S., \& Aziz, N. F. (2015). Corporate Social Responsibility: An Overview from Malaysia. Journal of Applied Environmental and Biological Sciences, 4(January), 82-87.

Musa, H., \& Chinniah, M. (2016). Malaysian SMEs Development: Future and Challenges on Going Green. Procedia - Social and Behavioral Sciences, 224, 254-262. https://doi.org/10.1016/j.sbspro.2016.05.457

Nejati, M., \& Amran, A. (2013). Corporate social responsibility terminologies in small businesses: insights from Malaysia. Business Strategy Series, 14(1), 11-14. https://doi.org/10.1108/17515631311295668 
Preuss, L. (2011). Innovative CSR: A framework for anchoring corporate social responsibility in the innovation literature. Journal of Corporate Citizenship, 44(Summer), 17-33.

SME Corporation Malaysia. (2018). SME Report 2018, 136.

Thorne, D. M., Ferrell, O. C., \& Ferrell, L. (2011). Business and Society: A Strategic Approach to Social Responsibility and Ethics (4th ed.).

UNICEF, U. N. C. F. (2013). Corporate Social Responsibility Policies in Malaysia. Retrieved from internal-pdf://0975650089/United Nations-2001-Corporate Social Responsib.pdf

World Business Council for Sustainable Development. (n.d.). Meeting Changing Expectations. WBCSD Publications. 